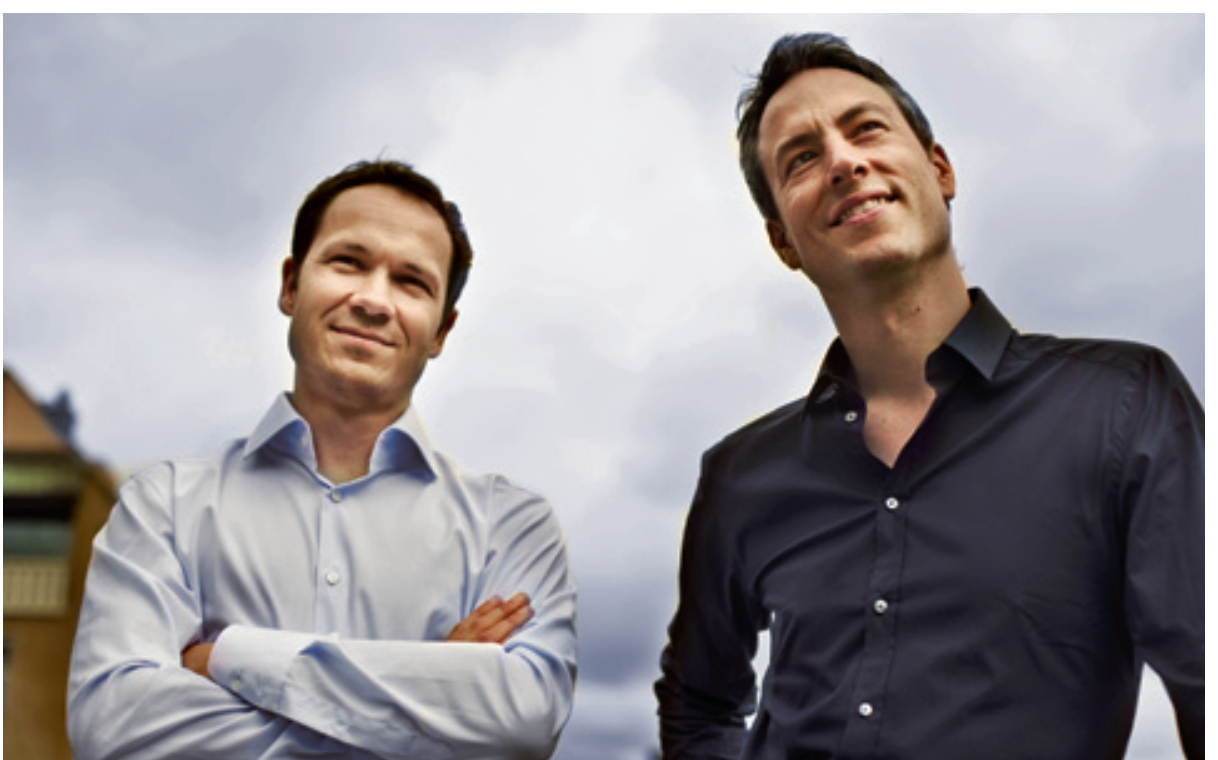

Torgeir T. Søvik (til høyre) og Erlend T. Aasheim, studiens første- og andreforfatter. Foto SCANPIX/Jon Eeg
Ordforklaringer

Sykelig fedme: $\mathrm{BMI}>40 \mathrm{~kg} / \mathrm{m}^{2}$ eller $>35 \mathrm{~kg} / \mathrm{m}^{2}$ med alvorlig vektrelatert tilleggssykdom, f.eks. type 2-diabetes eller obstruktiv søvnapné.

Gastrisk bypass: Øvre del av magesekken stiftes av til en lomme på ca. 25 ml. Jejunum deles og den distale delen av jejunum kobles til magesekkslommen. Magesekksresten og proksimale jejunum kobles til tynntarmen lenger distalt.

Duodenal omkobling: Store deler av magesekken fjernes og tynntarmen kobles om slik at næringsopptaket reduseres kraftig.

\title{
Hvilken fedmeoperasjon bør utføres ved ekstrem fedme?
}

Ved ekstrem fedme gir duodenal omkobling større vektreduksjon
enn gastrisk bypass, men ikke nødvendigvis større helsegevinster.

Forekomsten av overvekt og fedme har økt kraftig de siste tiårene, og særlig urovekkende er økningen i ekstreme former for fedme. Omtrent en av fem pasienter som opereres for fedme i Norge har en kroppsmasseindeks $(\mathrm{BMI})>50 \mathrm{~kg} / \mathrm{m}^{2}$.

Gastrisk bypass er den vanligste fedmeoperasjonen, men ved enkelte sentre brukes duodenal omkobling ved ekstrem fedme. Sammen med svenske forskere har vi nå for første gang sammenliknet gastrisk bypass med duodenal omkobling i en randomisert studie, blant pasienter med BMI $50-60 \mathrm{~kg} / \mathrm{m}^{2}(1)$.

- Vår hypotese var at duodenal omkobling ville gi større vektreduksjon enn gastrisk bypass, og dermed ytterligere helsegevinster i form av bedret kardiovaskulær risikoprofil og livskvalitet, sier førsteforfatter Torgeir T. Søvik ved Senter for sykelig overvekt i Helse Sør-Øst, Oslo universitetssykehus, Aker.

- Studien ga klare svar. For det første var prosentvis vektreduksjon mye større etter duodenal omkobling enn etter gastrisk bypass, med henholdsvis $45 \%$ og $31 \%$ kroppsvekttap etter to år. Dette innebærer at pasienter med ekstrem overvekt ofte vil ha betydelig fedme selv etter en gastrisk bypassoperasjon. Imidlertid førte begge operasjonene til store, og sammenliknbare, forbedringer i kardiovaskulære risikofaktorer. Unntaket var blodlipider der duodenal omkobling ga størst forbedringer. Til tross for den store forskjellen i vektreduksjon, var livskvaliteten betydelig bedret etter begge operasjonene. Duodenal omkobling medførte imidlertid flere komplikasjoner og flere ernæringsforstyrrelser.

- Ved ekstrem fedme gir fedmekirurgi store helsegevinster og bedret livskvalitet, men ikke nødvendigvis normalisert vekt. Duodenal omkobling kan kanskje tilbys utvalgte pasienter, men er forbundet med en større risiko enn gastrisk bypass, sier Søvik.

\section{Forskning på sykelig fedme}

Artikkelen er skrevet av Torgeir T. Søvik, Erlend T. Aasheim, Osama Taha,

My Engström, Morten W. Fagerland, Sofia Björkman, Jon Kristinsson, Kåre I. Birkeland, Tom Mala og Torsten Olbers. Søvik er lege i spesialisering og er i ferd med å avslutte sitt doktorgradsarbeid med Tom Mala som veileder. Studien er et samarbeid mellom Senter for sykelig overvekt i Helse Sør-Øst, Oslo universitetssykehus, Aker og Sahlgrenska Universitetssjukhuset i Göteborg.

\section{Erlend Hem}

erlend.hem@medisin.uio.no

Tidsskriftet

\section{Litteratur}

1. Søvik TT, Aasheim ET, Taha 0 et al. Weight loss, cardiovascular risk factors, and quality of life after gastric bypass and duodenal switch: a randomized trial. Ann Intern Med 2011; 155: 281-91.

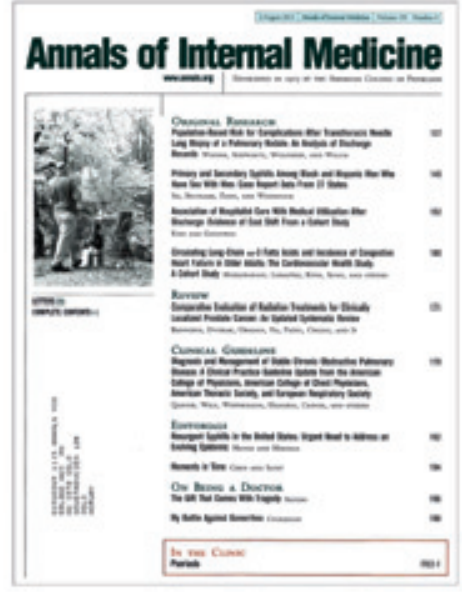

Artikkelen ble publisert 6.9. 2011 i Annals of Internal Medicine (www.annals.org) som regnes som en av de «fem store» innen medisinsk publisering ved siden av New England Journal of Medicine, JAMA, BMJ og The Lancet 